\title{
Influence of Cross-Breeding on Breed Features of Burzyan Bees
}

\author{
Arina S. Ishimguzhina \\ Department of Beekeeping, Small Animal Science, \\ Animal Breeding \\ Bashkir State Agrarian University \\ Ufa, Russia \\ e-mail: nefakt94@mail.ru
}

\author{
Aglyam Ya. Sharipov \\ Bashkir Research and Production Veterinary Laboratory \\ Ufa, Russia \\ e-mail: asharipov63@mail.ru
}

\begin{abstract}
The Burzyan population (Apis mellifera mellifera $L$.) of honeybees is considered the purest European dark bee breed in Russia. However, it is losing its thoroughbredness these days since its gene pool is intensively disturbed by southern imported bees. If left unaddressed, the brand asset of the Republic of Bashkortostan will not withstand the genetic influence of other bees and will soon disappear. There is a need for trustworthy information concerning the gene pool condition in order to develop the efficient program on conserving this bee breed. The paper provides the thoroughbredness assessment of bee families kept in private apiaries of six villages of the Burzyan district of the Republic of Bashkortostan. The study demonstrates the influence of cross-breeding on breed features of the Burzyan bees. The analysis based on the Breed by Wings software showed that the gene pool of the Burzyan population is primarily under the genetic pressure of caucasian honeybee.
\end{abstract}

Keywords-burzyan bee; traditional technique; computer program; share of southern bees; cubital index

\section{INTRODUCTION}

The Burzyan population (Apis mellifera mellifera L.) of honeybees is considered the purest European dark bee breed in Russia $[1 ; 2]$. It lives in the Burzyan district of the Republic of Bashkortostan. A famous zoologist and ecologist, professor of Moscow University G.A. Kozhevnikov, that headed an expedition in 1929-1930 to study the Burzyan bee, calls it "prehistoric" and encourages to protect it against crossbreeding since from the perspective of genetics it represents the greatest value [3]. Today the pure populations of the European dark bee became a national wealth of the country, they are extremely important for bee breeding in Russia and the world. Nowadays Russian breeders make the full use of a valuable gene pool of the Burzyan bee $[4 ; 5]$. Therefore, the genetic conservation of the Burzyan honeybee population became particularly relevant and requires active scientific and practical study [6]. It also became the matter of discussion at the level of the Government of the Republic of Bashkortostan thus resulting in specific actions on genetic conservation of this bee [7].

Unfortunately, today the gene pool of the Burzyan honeybee population is being disturbed by imported bees thus causing many concerns among beekeepers $[8 ; 9 ; 10]$.
The cross-breeding danger of the Burzyan bee first appeared in 1960s-1970s. At this time the planned development of frame beekeeping allowed importing packages to the republic from other regions of the country, which was supported by beekeepers that agitated for cross-breeding hybridization of bees [11]. Nevertheless, single cases of foreign bee import were recorded in the Burzyan district. Until 1970 s, bad forest roads in this region served a reliable source of preventing any transportation of bees via motor transport [12]. The import of bees of other breeds to the Republic of Bashkortostan increased sharply at the beginning of the $21^{\text {st }}$ century. As public apiaries developed and road conditions improved the cases of import of bee families, packages and queen bees to the republic from other regions became more frequent. Despite the law On Beekeeping and constantly accepted republican decisions to ban the import of foreign bee breeds to the habitat of the Burzyan bee, the import of unknown bee families to the Burzyan district was not reduced [13]. Currently, the purest population of the European dark bee is surrounded by crossbred bees, which threatens its existence as subspecies.

The conservation of the Burzyan bee became ever more relevant after the International Federation of Beekeepers' Associations decided to hold the $47^{\text {th }}$ International Apimondia Congress and the ApiEXPO exhibition in 2021 in the Republic of Bashkortostan. For many years now, the republic has been in the top list among honey producers in Russia, and has high potential in the international market. The most valuable variety of the Bashkir honey is the honey of the Burzyan bee. Thus, it surpasses the honey of southern bees in enzyme content by 4-5 times per unit volume. Hence, the Congress will pay considerable attention to the issue of conservation of this unique population.

With reference to the above, the purpose of the given study was to analyze the thoroughbredness of bee families within apiaries of the Burzyan district of the Republic of Bashkortostan. The main objective was to define the bee breed affiliation to external features. The study was performed in 2017.

\section{MATERIALS}

The bee samples were selected from six villages of the Burzyan district of the Republic of Bashkortostan: Kutanovo, 
Kiekbayevo, Atikovo, Gadelgareevo, Galiakberovo and Askarovo. In total, four samples were selected from each village, which in total make twenty-four samples. These samples were taken according to research procedures in beekeeping [14]. Fifty young specimen were selected from each bee family. They were scalded in boiled water and wrapped in a gauze bundle indicating the owner of a private apiary, number of a bee family, date of breeding and name of the village. Then the bee samples were filled with $70 \%$ ethyl alcohol and stored before preparation.

\section{METHODS}

The breed affiliation of bees was determined via traditional technique of V.V. Alpatov [15]. The measurements were made using MBS-9 binocular microscope. The following external features were studied: proboscis length, length of third tergite, length and width of wax foundation, length and width of the right forewing, cubital index and tarsal index. The range of parameter values variation was studied through $C_{v}$ variation coefficient. The breed affiliation of bee families was based on the cubital index, while others were only used as auxiliary features.

The purity test of a local bee was also studied using the Breed by Wings domestic software designed by A.B. Kartashev in Excel format [16]. The coordinates of eight points of the right forewing designed by the tpsDig2 software were used in this program as source data. Three indicators, namely the cubital index, discoidal shift and dumb-bell index, formed the basis of breed defining features.

The software value is that it is able to calculate a share of pure and crossbred bees in relation to the studied bee family. It is known that the traditional technique reveals only the affiliation of bees to a certain breed.

To study the influence of cross-breeding on breed features of local bees the obtained data was compared and analyzed with the study of such researchers as V.G. Heinrich and V.A. Tyulpanova (1958) performed in the Burzyan district of the republic half a century ago [17]. In 1960s, the Burzyan population lived in this region in its pure form and the problem of bee cross-breeding did not exist

\section{RESULTS AND DISCUSSION}

Tables 1-7 show the results of the study.

\section{A. Values of external anatomy features in Kutanovo village.}

The cubital index makes $57.90 \pm 0.74 \%$, it ranges from $42.53 \%$ to $72.34 \%$, variability coefficient -10.51 . These data make it possible to conclude that the bees of this village are subject to cross-breeding.

The computer analysis also confirms this conclusion. For example, according to traditional technique, the bee family No. 2 was defined as thoroughbred, while the Breed by Wings software revealed some share of caucasian honeybee: $9.4 \%$ (Fig. 1).
TABLE I. EXTERNAL ANATOMY FEATURES OF BEES IN KUTANOVO VILLAGE $(\mathrm{N}=200,2017)$

\begin{tabular}{|l|c|c|c|}
\hline \multicolumn{1}{|c|}{$\mathbf{x}$} & $\mathbf{M} \pm \mathbf{m}$ & $\mathbf{l i m}$ & $\mathbf{C v}, \mathbf{\%}$ \\
\hline Proboscis length, mm & $6.19 \pm 0.01$ & $6.12-6.38$ & 1.34 \\
\hline $\begin{array}{l}\text { Length of third tergite } \\
\text { mm }\end{array}$ & $2.37 \pm 0.01$ & $2.21-2.28$ & 3.51 \\
\hline $\begin{array}{l}\text { Length of third sternite, } \\
\text { mm }\end{array}$ & $3.01 \pm 0.04$ & $2.29-3.36$ & 4.32 \\
\hline $\begin{array}{l}\text { Width of wax foundation, } \\
\text { mm }\end{array}$ & $2.70 \pm 0.03$ & $2.20-3.36$ & 3.31 \\
\hline $\begin{array}{l}\text { Length of wax } \\
\text { foundation, mm }\end{array}$ & $1.59 \pm 0.03$ & $1.18-1.72$ & 5.16 \\
\hline Length of forewing, mm & $9.27 \pm 0.01$ & $8.31-9.46$ & 2.48 \\
\hline Width of forewing, mm & $3.23 \pm 0.01$ & $2.82-3.63$ & 3.26 \\
\hline Tarsal index, \% & $53.35 \pm 0.38$ & $47.21-61.92$ & 4.71 \\
\hline Cubital index, \% & $57.90 \pm 0.74$ & $42.53-72.34$ & 10.51 \\
\hline
\end{tabular}

The cubital index makes $57.90 \pm 0.74 \%$, it ranges from $42.53 \%$ to $72.34 \%$, variability coefficient -10.51 . These data make it possible to conclude that the bees of this village are subject to cross-breeding.

The computer analysis also confirms this conclusion. For example, according to traditional technique, the bee family No. 2 was defined as thoroughbred, while the Breed by Wings software revealed some share of caucasian honeybee: $9.4 \%$ (Fig. 1).

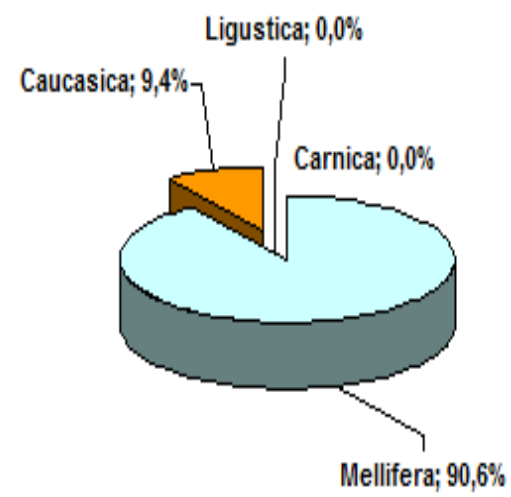

QMellifera पCaucasica uLigustica QCarnica

Fig. 1. Computer analysis of bee family No. 2 (Gadelshin R.G., Kutanovo village)

B. Values of external anatomy features in Kiekbayevo village

The cubital index makes $59.34 \pm 0.60 \%$. The variation limits of its parameters fall within the range from $54.82 \%$ to $80.47 \%$. The variability coefficient makes 8.70 . Thus, it is possible to conclude that the bee families of Kiekbayevo village preserved their purity. Nevertheless, the computer analysis revealed a share of southern bees in one studied bee family: the share of other bees, namely caucasian honey bee, made $3.3 \%$ (Fig. 2). 


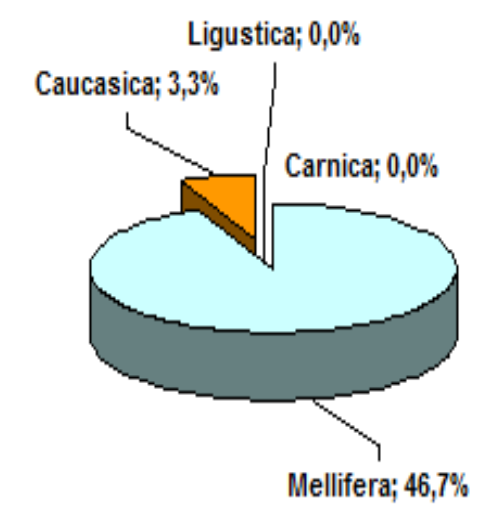

口Mellifera uCaucasica uLigustica QCarnica

Fig. 2. Computer analysis of bee family No. 4 (Ryskulova V.Z., Kiekbayevo village)

TABLE II. EXTERNAL ANATOMY FEATURES OF BEES IN KIEKBAYEVO VILLAGE $(\mathrm{N}=200,2017)$

\begin{tabular}{|l|c|c|c|}
\hline \multicolumn{1}{|c|}{$\begin{array}{c}\text { External } \\
\text { anatomy features }\end{array}$} & $\boldsymbol{M} \pm \boldsymbol{m}$ & $\lim$ & $\boldsymbol{C}_{\boldsymbol{v}}, \boldsymbol{\%}$ \\
\hline $\begin{array}{l}\text { Proboscis length, } \\
\text { mm }\end{array}$ & $6.22 \pm 0.01$ & $5.85-6.26$ & 1.98 \\
\hline $\begin{array}{l}\text { Length of third } \\
\text { tergite, mm }\end{array}$ & $2.36 \pm 0.01$ & $2.33-2.44$ & 3.51 \\
\hline $\begin{array}{l}\text { Length of third } \\
\text { sternite, } \mathrm{mm}\end{array}$ & $2.99 \pm 0.03$ & $2.29-3.36$ & 1.78 \\
\hline $\begin{array}{l}\text { Width of wax } \\
\text { foundation, mm }\end{array}$ & $2.74 \pm 0.02$ & $2.53-2.98$ & 3.87 \\
\hline $\begin{array}{l}\text { Length of wax } \\
\text { foundation, mm }\end{array}$ & $1.67 \pm 0.02$ & $1.49-1.77$ & 4.12 \\
\hline $\begin{array}{l}\text { Length of } \\
\text { forewing, mm }\end{array}$ & $9.22 \pm 0.04$ & $9.11-9.27$ & 3.29 \\
\hline $\begin{array}{l}\text { Width of } \\
\text { forewing, mm }\end{array}$ & $3.21 \pm 0.01$ & $3.02-3.33$ & 5.03 \\
\hline Tarsal index, \% & $55.29 \pm 0.38$ & $48.34-58.22$ & 2.48 \\
\hline Cubital index, \% & $59.34 \pm 0.60$ & $54.82-80.47$ & 8.70 \\
\hline
\end{tabular}

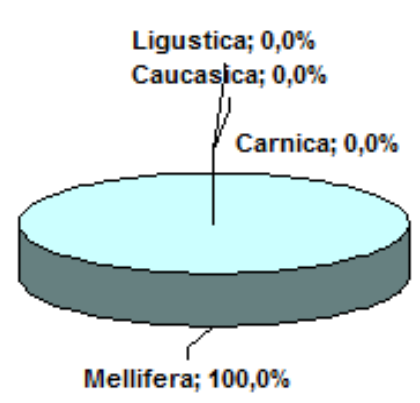

$\square$ Mellifera $\square$ Caucasica $\square$ Ligustica $\square$ Carnica

Fig. 3. . Computer analysis of bee family No. 4 (Gadamshin Sh.Z., Atikovo village)
C. Values of external anatomy features in Atikovo village

The cubital index makes $59.22 \pm 0.56 \%$, it ranges from $55.82 \%$ to $68.32 \%$, variability coefficient -6.56 . It is possible to conclude that the bee families of Atikovo village preserved their purity. The computer analysis also did not reveal any share of southern bees (Fig. 3).

TABLE III. EXTERNAL ANATOMY FEATURES OF BEES IN ATIKOVO VILLAGE $(\mathrm{N}=200,2017)$

\begin{tabular}{|l|c|c|c|}
\hline \multicolumn{1}{|c|}{$\begin{array}{c}\text { External } \\
\text { anatomy } \\
\text { features }\end{array}$} & $\boldsymbol{M} \pm \boldsymbol{m}$ & $\boldsymbol{l i m}$ & $\boldsymbol{C}_{\boldsymbol{v}}, \boldsymbol{\%}$ \\
\hline $\begin{array}{l}\text { Proboscis } \\
\text { length, mm }\end{array}$ & $6.12 \pm 0.03$ & $5.88-6.36$ & 2.12 \\
\hline $\begin{array}{l}\text { Length of third } \\
\text { tergite, mm }\end{array}$ & $2.36 \pm 0.01$ & $2.16-2.54$ & 3.26 \\
\hline $\begin{array}{l}\text { Length of third } \\
\text { sternite, mm }\end{array}$ & $2.92 \pm 0.04$ & $2.68-3.26$ & 2.17 \\
\hline $\begin{array}{l}\text { Width of wax } \\
\text { foundation, mm }\end{array}$ & $2.49 \pm 0.03$ & $2.34-2.87$ & 2.66 \\
\hline $\begin{array}{l}\text { Length of wax } \\
\text { foundation, mm }\end{array}$ & $1.58 \pm 0.03$ & $1.42-1.80$ & 2.63 \\
\hline $\begin{array}{l}\text { Length of } \\
\text { forewing, mm }\end{array}$ & $9.24 \pm 0.02$ & $9.12-9.42$ & 5.03 \\
\hline $\begin{array}{l}\text { Width of } \\
\text { forewing, mm }\end{array}$ & $3.22 \pm 0.01$ & $3.02-3.33$ & 4.96 \\
\hline Tarsal index, \% & $55.34 \pm 0.33$ & $52.04-6010$ & 6.56 \\
\hline $\begin{array}{l}\text { Cubital index, } \\
\%\end{array}$ & $59.22 \pm 0.56$ & $55.20-68.32$ & \\
\hline
\end{tabular}

D. Values of external anatomy features in Gadelgareevo village

The cubital index of bee families of this village $(60.10 \pm 0.68 \%)$ corresponds to breed standards $(60.00 \%$ and above). It ranges from $46.53 \%$ to $74.42 \%$. The variability coefficient makes 12.87 . It is possible to conclude that the bee families of Gadelgareevo village preserved their purity. The computer analysis also did not reveal any share of southern bees (Fig. 4).

TABLE IV. EXTERNAL ANATOMY FEATURES OF BEES IN GADELGAREEVO VILLAGE $(\mathrm{N}=200,2017)$

\begin{tabular}{|c|c|c|c|}
\hline $\begin{array}{c}\text { External } \\
\text { anatomy } \\
\text { features }\end{array}$ & $\boldsymbol{M} \pm \boldsymbol{m}$ & $\boldsymbol{l i m}$ & $\boldsymbol{C}_{\boldsymbol{v}}, \boldsymbol{\%}$ \\
\hline $\begin{array}{c}\text { Proboscis } \\
\text { length, mm }\end{array}$ & $6.19 \pm 0.02$ & $5.78-6.86$ & 4.61 \\
\hline $\begin{array}{c}\text { Length of third } \\
\text { tergite, mm }\end{array}$ & $2.34 \pm 0.01$ & $2.26-2.49$ & 3.89 \\
\hline $\begin{array}{c}\text { Length of third } \\
\text { sternite, mm }\end{array}$ & $2.87 \pm 0.04$ & $2.39-3.12$ & 5.08 \\
\hline $\begin{array}{c}\text { Width of wax } \\
\text { foundation, mm }\end{array}$ & $2.48 \pm 0.02$ & $2.30-2.68$ & 3.83 \\
\hline $\begin{array}{c}\text { Length of wax } \\
\text { foundation, mm }\end{array}$ & $1.61 \pm 0.03$ & $1.48-1.92$ & 1.88 \\
\hline $\begin{array}{c}\text { Length of } \\
\text { forewing, mm }\end{array}$ & $9.23 \pm 0.02$ & $8.12-9.46$ & 1.88 \\
\hline $\begin{array}{c}\text { Width of } \\
\text { forewing, mm }\end{array}$ & $3.18 \pm 0.01$ & $3.07-3.26$ & 4.67 \\
\hline Tarsal index, \% & $54.98 \pm 0.29$ & $50.72-62.36$ & 12.87 \\
\hline $\begin{array}{c}\text { Cubital index, } \\
\%\end{array}$ & $60.10 \pm 0.68$ & $46.53-74.42$ & \\
\hline
\end{tabular}




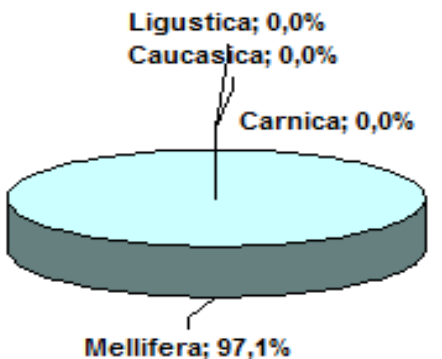

$\square$ Mellifera $\square$ Caucasica $\square$ Ligustica $\square$ Carnica

Fig. 4. . Computer analysis of bee family No. 2 (Asigulov R.T., Galiakberovo village)

\section{E. Values of external anatomy features in Galiakberovo village}

The bee families of this village have low cubital index: $58.86 \pm 0.72 \%$. At the same time its value strongly ranges from $48.66 \%$ to $72.60 \%$. The variability coefficient is high: $14: 48$. These data make it possible to conclude that the bees of this village are subject to cross-breeding. The computer analysis also confirms this conclusion. For example, the share of caucasian honey bee within the studied bee family No. 1 makes $5.7 \%$ (Fig. 5)

TABLE V. . EXTERNAL ANATOMY FEATURES OF BEES IN GALIAKBEROVO VILLAGE

\begin{tabular}{|c|c|c|c|}
\hline $\begin{array}{c}\text { External } \\
\text { anatomy } \\
\text { features }\end{array}$ & $\boldsymbol{M} \pm \boldsymbol{m}$ & $\boldsymbol{l i m}$ & $\boldsymbol{C}_{\boldsymbol{v}}, \boldsymbol{\%}$ \\
\hline $\begin{array}{c}\text { Proboscis } \\
\text { length, mm }\end{array}$ & $6.12 \pm 0.01$ & $5.54-6.97$ & 5.12 \\
\hline $\begin{array}{c}\text { Length of third } \\
\text { tergite, mm }\end{array}$ & $2.37 \pm 0.02$ & $2.21-2.52$ & 3.12 \\
\hline $\begin{array}{c}\text { Length of third } \\
\text { sternite, mm }\end{array}$ & $2.89 \pm 0.03$ & $2.52-3.26$ & 4.88 \\
\hline $\begin{array}{c}\text { Width of wax } \\
\text { foundation, mm }\end{array}$ & $2.50 \pm 0.03$ & $2.34-2.68$ & 3.17 \\
\hline $\begin{array}{c}\text { Length of wax } \\
\text { foundation, mm }\end{array}$ & $1.72 \pm 0.02$ & $1.52-1.92$ & 6.81 \\
\hline $\begin{array}{c}\text { Length of } \\
\text { forewing, mm }\end{array}$ & $9.22 \pm 0.03$ & $8.06-9.29$ & 2.01 \\
\hline $\begin{array}{c}\text { Width of } \\
\text { forewing, mm }\end{array}$ & $3.11 \pm 0.02$ & $3.08-3.22$ & 1.67 \\
\hline Tarsal index, \% & $55.07 \pm 0.30$ & $52.34-60.92$ & 5.83 \\
\hline $\begin{array}{c}\text { Cubital index, } \\
\%\end{array}$ & $58.86 \pm 0.72$ & $48.66-72.60$ & 14.48 \\
\hline
\end{tabular}

\section{F. Values of external anatomy features in Askarovo village}

In comparison with similar indicators of bees of other villages, the bee families of Askarovo village have the lowest cubital index: $57.44 \pm 0.59 \%$. It ranges from $36.58 \%$ to $67.88 \%$. The variability coefficient makes 16.32 . It is possible to conclude that the bees of this village are strongly subjected to cross-breeding. The computer analysis also confirms this conclusion. Thus, the share of caucasian honey bee within the studied bee family No. 4 makes $17.1 \%$ (Fig. 6).

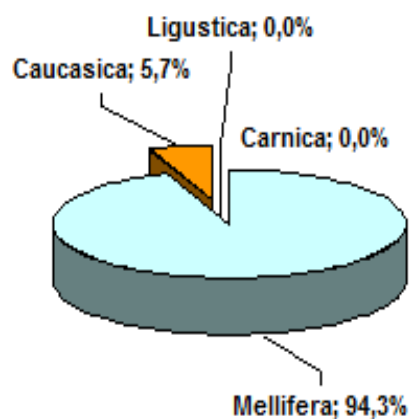

\section{口Mellifera aCaucasica aLigustica $\square$ Carnica}

Fig. 5. . Computer analysis of bee family No. 1 (Baygazin I.M., Galiakberovo village)

TABLE VI. TABLE VI. EXTERNAL ANATOMY FEATURES OF BEES IN ASKAROVO VILLAGE $(\mathrm{N}=200,2017)$

\begin{tabular}{|c|c|c|c|}
\hline $\begin{array}{c}\text { External } \\
\text { anatomy } \\
\text { features }\end{array}$ & $\boldsymbol{M} \pm \boldsymbol{m}$ & $\boldsymbol{l i m}$ & $\boldsymbol{C}_{\boldsymbol{v}}, \boldsymbol{\%}$ \\
\hline $\begin{array}{c}\text { Proboscis } \\
\text { length, mm }\end{array}$ & $6.12 \pm 0.01$ & $5.54-6.97$ & 5.12 \\
\hline $\begin{array}{c}\text { Length of third } \\
\text { tergite, mm }\end{array}$ & $2.37 \pm 0.02$ & $2.21-2.52$ & 3.12 \\
\hline $\begin{array}{c}\text { Length of third } \\
\text { sternite, mm }\end{array}$ & $2.89 \pm 0.03$ & $2.52-3.26$ & 4.88 \\
\hline $\begin{array}{c}\text { Width of wax } \\
\text { foundation, mm }\end{array}$ & $2.50 \pm 0.03$ & $2.34-2.68$ & 3.17 \\
\hline $\begin{array}{c}\text { Length of wax } \\
\text { foundation, mm }\end{array}$ & $1.72 \pm 0.02$ & $1.52-1.92$ & 6.81 \\
\hline $\begin{array}{c}\text { Length of } \\
\text { forewing, mm }\end{array}$ & $9.22 \pm 0.03$ & $8.06-9.29$ & 2.01 \\
\hline $\begin{array}{c}\text { Width of } \\
\text { forewing, mm }\end{array}$ & $3.11 \pm 0.02$ & $3.08-3.22$ & 1.67 \\
\hline Tarsal index, \% & $55.07 \pm 0.30$ & $52.34-60.92$ & 5.83 \\
\hline $\begin{array}{c}\text { Cubital index, } \\
\%\end{array}$ & $58.86 \pm 0.72$ & $48.66-72.60$ & 14.48 \\
\hline
\end{tabular}

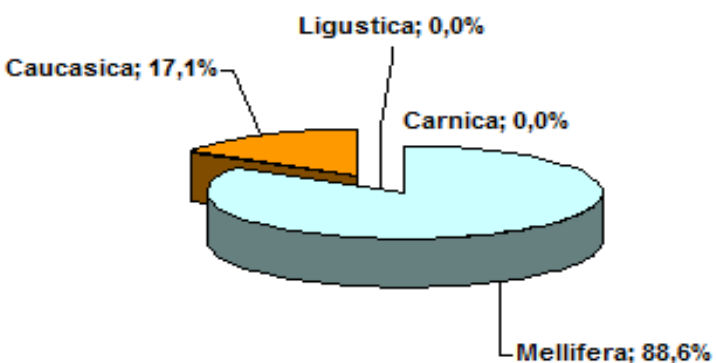

$\square$ Mellifera $\square$ Caucasica $\square$ Ligustica $\square$ Carnica

Fig. 6. . Computer analysis of bee family No. 4 (Ibragimov Yu.A., Askarovo village) 
G. Influence of cross-breeding on breed features of local bees

Table 7 shows the dynamics of external anatomy features of local bees over 1958 and 2017.

TABLE VII. DYNAMICS OF EXTERNAL ANATOMY FEATURES OF BURZYAN BEES OVER 1958 AND 2017

\begin{tabular}{|l|c|c|}
\hline \multirow{2}{*}{\multicolumn{1}{|c|}{ External anatomy features }} & $\mathbf{1 9 5 8}$ & $\mathbf{2 0 1 7}$ \\
\cline { 2 - 3 } & $\boldsymbol{M} \pm \boldsymbol{m}$ & $\boldsymbol{l i m}$ \\
\hline Proboscis length, $\mathrm{mm}$ & $6.10 \pm 0.005$ & $6.12-6.22$ \\
\hline Length of third tergite, $\mathrm{mm}$ & $2.32 \pm 0.012$ & $2.28-2.37$ \\
\hline Length of third sternite, $\mathrm{mm}$ & $2.90 \pm 0.004$ & $2.87-3.01$ \\
\hline Width of wax foundation, $\mathrm{mm}$ & $2.49 \pm 0.007$ & $2.48-2.74$ \\
\hline Length of wax foundation, $\mathrm{mm}$ & $1.74 \pm 0.003$ & $1.58-1.72$ \\
\hline Length of forewing, $\mathrm{mm}$ & $9.23 \pm 0.008$ & $9.22-9.28$ \\
\hline Width of forewing, $\mathrm{mm}$ & $3.06 \pm 0.003$ & $3.11-3.23$ \\
\hline Tarsal index, \% & $53.38 \pm 0.08$ & $53.04-55.05$ \\
\hline Cubital index, \% & $61.95 \pm 0.09$ & $57.44-60.10$ \\
\hline
\end{tabular}

The analysis of these external features of 2017 shows that in comparison with 1958 some features increased while the others decreased:

- $\quad$ average proboscis length increased from 6.10 to 6.22 $\mathrm{mm}$;

- length of the third tergite $(2.32 \mathrm{~mm})$ almost remained at the same level $(2.28-2.37 \mathrm{~mm})$;

- length of the third sternite $(2.90 \mathrm{~mm})$ also has minor differences (2.87-3.01 mm);

- width of wax foundation definitely increased from 2.49 to $2.74 \mathrm{~mm}$;

- length of wax foundation definitely decreased from 1.74 to $1.58 \mathrm{~mm}$;

- length of the right forewing increased from 9.23 to $9.28 \mathrm{~mm}$;

- width of the right forewing increased from 3.06 to $3.23 \mathrm{~mm}$;

- tarsal index increased from $53.38 \%$ to $55.05 \%$;

- cubital index significantly decreased from $61.95 \%$ to $57.44 \%$.

We assume that these changes happened under the influence of bee cross-breeding.

\section{FINDINGS}

1. Today in a gene pool of the Burzyan population the share of bees with cross-breeding features reaches $17.1 \%$.

2. Local bee families are exposed to cross-breeding, mainly from caucasian honey bees.

3. As a result of bee cross-breeding the cubital index sharply decreased from $61.95 \%$ to $57.44 \%$.

\section{CONCLUSIONS}

It is found that today the gene pool of the Burzyan bee is mainly being disturbed by caucasian honeybees. Without the human aid, the aboriginal bee will not recover its thoroughbredness. This situation requires urgent and efficient measures. Alongside with the study of cross-breeding of the Burzyan bee according to external features, the population and genetic study are considered critical [18]. We believe that in relation to the Burzyan bee the study conducted by A.G. Nikolenko and A.V. Poskryakov [19] are the most promising.

\section{References}

[1] V.N. Sattarov, M.G. Migranov, "Population and genetic polymorphism of the Bashkir population of the European dark bee Apis mellifera mellifera L., International Journal of Applied and Fundamental Research, 2011, No. 7, pp. 11-12.

[2] R.A. Ilyasov, A.V. Poskryakov, A.V. Petukhov, A.G. Nikolenko, "Genetic differentiation of local populations of a dark forest bee Apis mellifera mellifera L. in the Urals", Genetics, 2015, vol. 51, No. 7, pp. 792-798.

[3] . G.A Kozhevnikov, "Breeds of bees and ways of their improvement", Moscow, New Village Publishing House, 1929, pp. 80.

[4] A.Ya. Sharipov, "Assessment methods of breeding features of wild hive bees", Beekeeping, 2011, No. 10, pp. 10-11.

[5] M.G. Giniyatullin, V.R.Tuktarov, "Stock breeding in beekeeping of the Republic, Dark forest bee Apis mellifera mellifera $L$. of the Republic of Bashkortostan", Shulgan-Tash Nature Reserve, Bashkir State Agrarian University, Moscow, 2016, pp. 96-104..

[6] A.S. Ishimguzhina, "Problems of genetic conservation of Burzyan wild hive bees, Problems of scientific thought", 2018, vol. 4, No. 3, pp. 095097.

[7] N. Schmidt, "International Congress of Apimondia to be held in Russia, Beekeeping", 2018, No. 1, pp. 3-5..

[8] A.G. Nikolenko, S.A. Fakhretdinova, R.A. Ilyasov, A.V. Poskryakov, "Area of Burzyan population of a dark forest bee Apis mellifera mellifera L.", Works of the Russian entomological society, 2010, vol. 81, No. 4, pp. 57-64.

[9] R.A. Ilyasov, A.V. Poskryakov, A.G. Nikolenko, "Monitoring (20042015) of a gene pool of a dark forest bee of the Burzyan population of Apis mellifera mellifera", Study of Bashkortostan nature and the problem of beekeeping, Ufa: Informreklama, 2016, pp. 148-161.

[10] F.G Yumaguzhin, F.G. Talipov, A.N. Talipov, "State of a gene pool of the Burzyan wild hive bee", Study of Bashkortostan nature and the problem of beekeeping, Ufa: Informreklama, 2016, pp. 186-191.

[11] R.I. Gazizov, "Breeding improvement of local bees in Bashkiria, Beekeeping", 1987, No. 5, pp. 7-8.

[12] M.N. Kosarev, "Preservation of a gene pool of the Bashkir bee, Beekeeping:, 2008, No. 7, pp. 15-17.

[13] F.G. Yumaguzhin, "Biomorphological and population adaptation of the Burzyan wild hive bee", extended abstract of Dr.Sci.Biol. Dissertation, Saransk, 2014, p. 42.

[14] A.V. Borodachev, "Study resuls in bee breeding over 2001-2005, Collection of research works on beekeeping", Rybnoye, 2005, pp. 66-73.

[15] V.V. Alpatov, "Breeds of a honey bee", Moscow: Society of nature investigators, 1948, p. 143.

[16] A.B. Kartashev, "Elite queen of the European dark bee", Beekeeping, 2013, No. 7, pp. 13-16.

[17] V.G. Heinrich, V.A. Tyulpanova, "Bashkir wild hive bees", Beekeeping, 1958, No. 8, pp. 24-27.

[18] A.B. Jensen, K.A. Palmer, J.J. Boomsma and B.V. Pedersen, "Varying degrees of Apis mellifera ligustica introgression in protected populations 
of the black honeybee Apis mellifera mellifera in northwest Europe", Molecular Ecology, 2005, vol. 14, pp. 93-106.
[19] A.G. Nikolenko, A.V. Poskryakov, "Polymorphism of COI-COII locus of mitochondrial DNA of Apis mellifera L. in South Ural", Genetics, 2002, vol. 38, No. 4, pp. 458-462. 